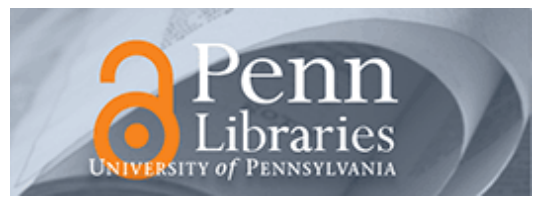

Studies in Visual Communication

Volume 7

Issue 3 Summer 1981

Article 3

1981

\title{
The Eyes of the Proletariat: The Worker-Photography Movement in Weimar Germany
}

Hanno Hardt

Karin B. Ohrn

Recommended Citation

Hardt, H., \& Ohrn, K. B. (1981). The Eyes of the Proletariat: The Worker-Photography Movement in Weimar Germany. 7(3), 46-57. Retrieved from https://repository.upenn.edu/svc/vol7/iss3/3

This paper is posted at ScholarlyCommons. https://repository.upenn.edu/svc/vol7/iss3/3

For more information, please contact repository@pobox.upenn.edu. 
The Eyes of the Proletariat: The Worker-Photography Movement in Weimar Germany 


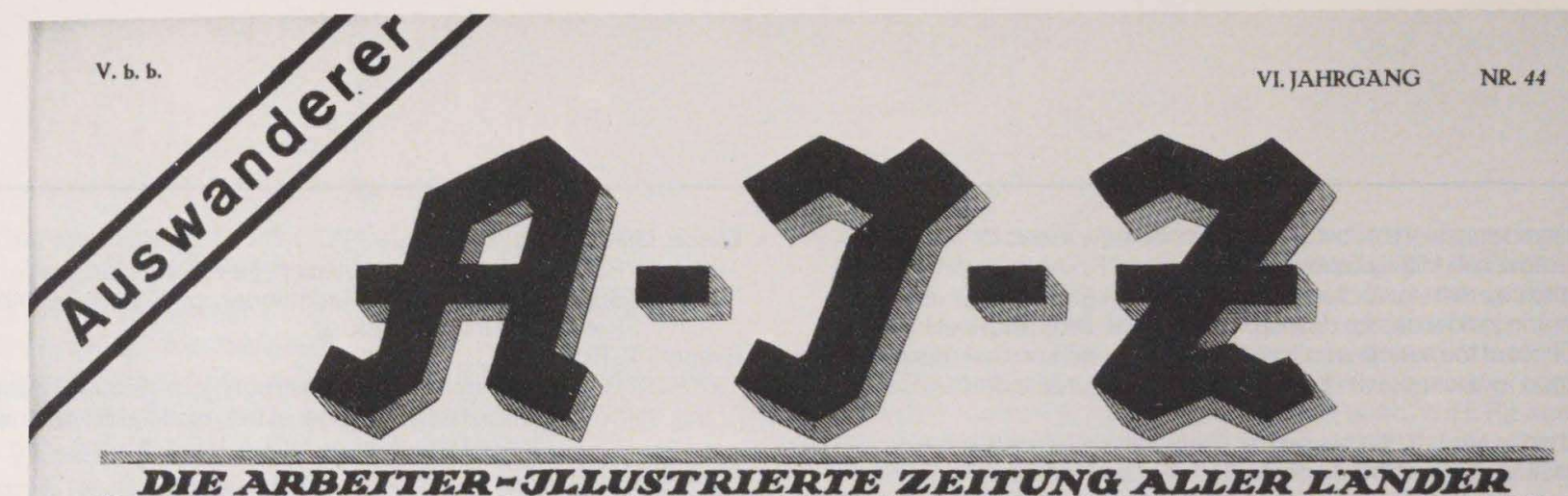

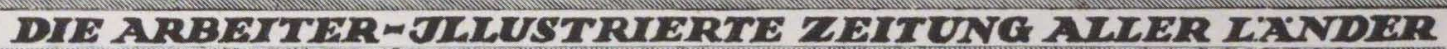

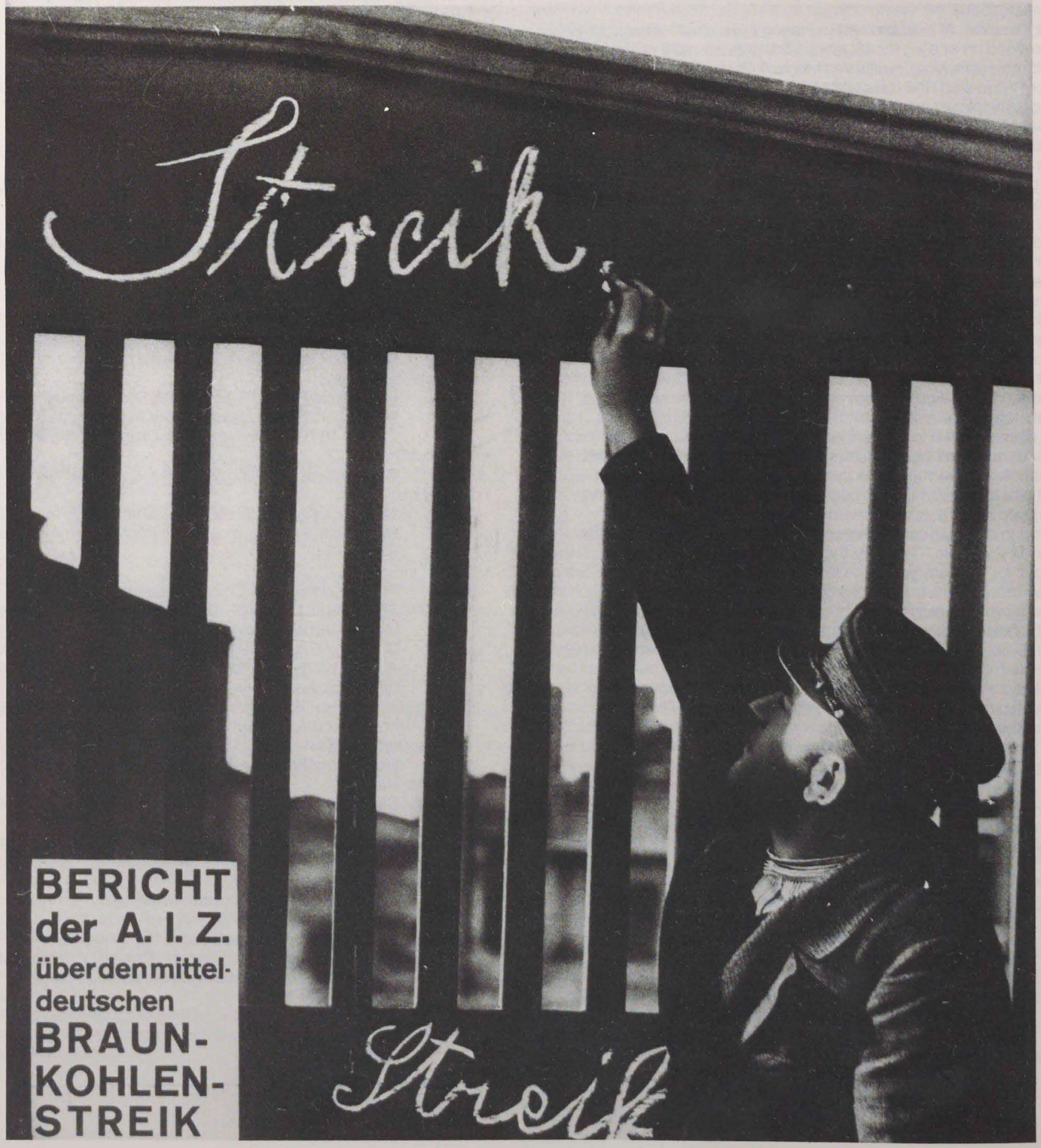




\title{
The Eyes of the Proletariat: The Worker-Photography Movement in Weimar Germany
}

\author{
Hanno Hardt and Karin B. Ohrn
}

You must all come before my camera:

Honourable gentlemen with close-cropped hair,

Veterans of student duels,

You must all come before my camera:

Ladies in automobiles,

I want to take aim at your high breasts,

You must all come before my camera:

I capture you with my flashlight,

All you champagne-drinking parasites,

And I want the rest before my camera too:

The hospital with its suffering and distress,

The screams of women in childbirth,

And then the final picture in my camera:

Flags of victory all over the world,

And human beings holding one another's hand.

(Max Dortu, Come before My Camera, ca. 1930)

Weimar Germany was born in a climate of politics, art, literature and science that introduced new forms of expression as artists and writers responded to the excitement and turmoil of the young republic. Their creative efforts were an expression, too, of a political engagement shared by many. As George Grosz recalls: "If the times are uneasy, if the foundation of society is under attack, then the artist cannot merely stand aside; especially not the talented artist with his finer sense of history. Therefore he becomes, whether he wants to or not, political" (Von Eckardt and Gilman 1975:76).

Popular magazines became an important vehicle for artistic and intellectual expression, in particular for new combinations of words and pictures dealing with contemporary events. The stimulus of political journalism, as exemplified by Carl von Ossietzky and his Weltbühne, thus found commercial application in newspapers and magazines appealing to mass audiences. And, as photographs began to appear regularly on magazine covers and with greater frequency inside, they took precedence for the first time over text as the primary journalistic medium.

Hanno Hardt is Professor of Journalism and Mass Communication at the University of lowa.

Karin B. Ohrn is Associate Professor of Journalism and Mass Communication at the University of lowa.
Old magazines from well-established publishing houses such as Ullstein's Berliner Illustrierte Zeitung (founded in 1890) were gradually redesigned to take advantage of this trend toward journalistic photography. New independent magazines, such as the Münchner Illustrierte Presse and the Kölmische Illustrierte Zeitung (founded in 1923 and 1926), overcame their provincialism in part by using photography to establish a cosmopolitan content and appeal. Nor was there any question that photographs could be directed toward political goals, for picture magazines covered the range of the political spectrum: from the National Socialist's Der Illustrierte Beobachter (1926) to the Communist party's principal organ, Die Arbeiter-Illustrierte Zeitung (1921). By 1926, there were over 30 picture magazines being published in Germany.

This appetite for photographs created new problems for magazines. The task of getting a volume of pictures of visually interesting subjects, then displaying it effectively, demanded new creative talents. Those with interest and ability quickly gained the power to shape the character of publications, in particular to express their political convictions through the coverage of events in their magazines.

Many of Germany's leading journalists during the prewar period were opposed to Hitler, and the picture editors of the three largest magazines were among them: Kurt Korff, editor of the Berliner Illustrierte; Paul Feinhals, who in 1930 moved from the Münchner Illustrierte to the Kölnische Illustrierte; and Stefan Lorant, who became editor of the Münchner Illustrierte Presse in 1928, and carried the magazine's cosmopolitan policy into its use of photographs. In various ways these men insured that the photographic content of their magazines avoided any allegiance with the National Socialist party. Lorant, for example, refused to publish any photographs of Adolf Hitler, and used humorously juxtaposed photographs to comment on liberal politicians who appeared naive about the Nazi threat. Each of these magazines published photo essays on different aspects of the lives of common people, but carefully omitted the glorification of Aryan traits that dominated the Nazi portrayal of the German people in Der Illustrierte Beobachter.

The photographers and newly formed picture agencies supplying work to these magazines appear to have supported these editors' views. Many photographers had forbidden the agencies to submit their work to Der Illustrierte Beobachter (Gidal 1973:26), and in 1933, most of the prominent ones-including many non-Jews - left Germany rather than submit to Nazi control of the press. 


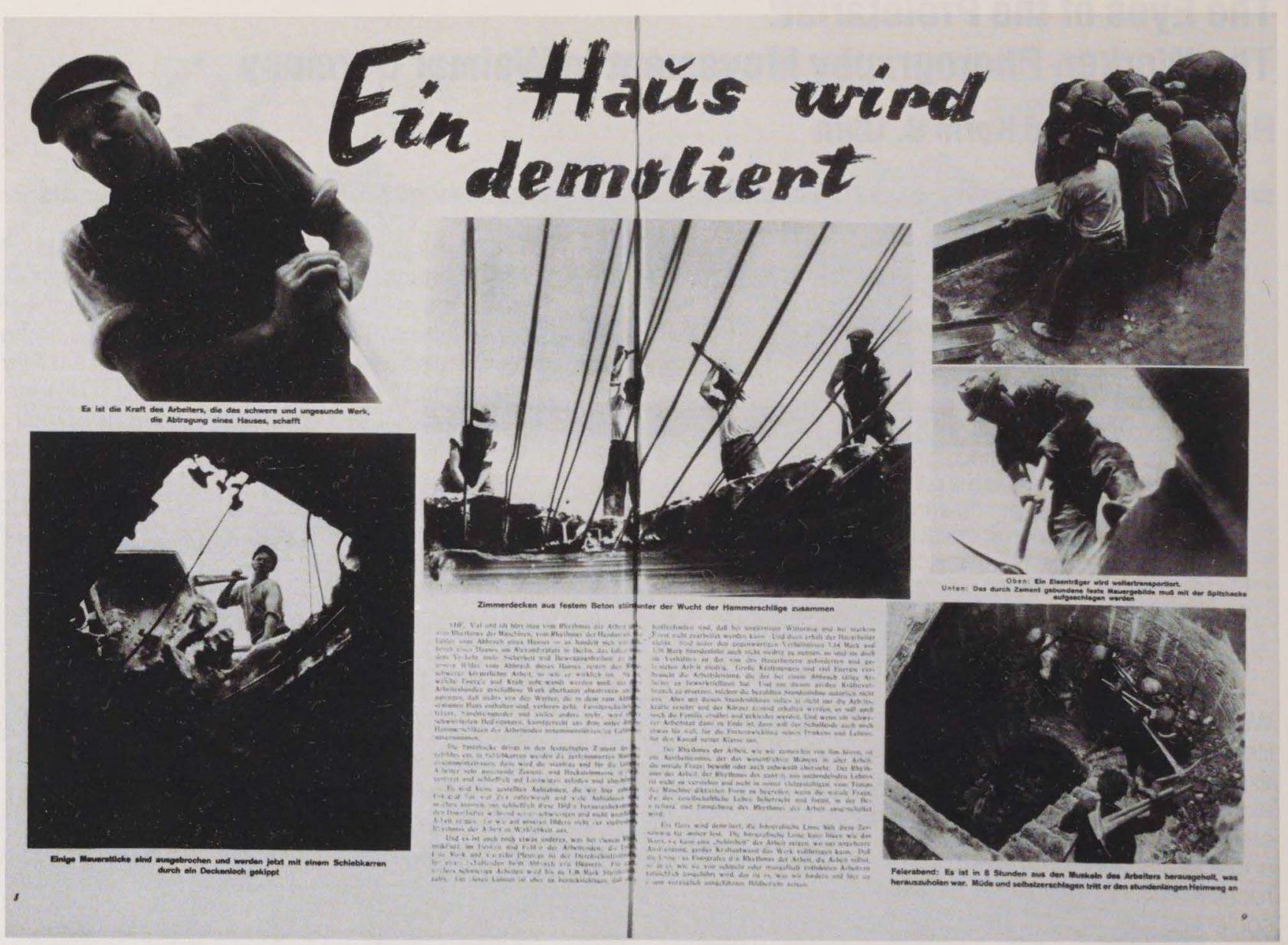

Figure 2 The end of the economic crisis: an optimistic account of rising employment, improved sales, and productivity. Münchner Illustrierte Presse, Volume 11, Number 46 (1932), pp. 1282-1283.

From the perspective of the radical left, however, the new German photojournalism was offering a weak and limited critique of the forces that were reshaping German society. The Arbeiter-Illustrierte Zeitung (AIZ) was founded specifically to correct and extend the liberal critique of Nazism offered by the bourgeois press. In order to carry out this goal, it was necessary to establish an organizational network independent of those that fed into Germany's emerging picture press. Unlike its bourgeois counterparts, the network that provided work for the $A I Z$ was based on a view of both the medium and the practice of photography as explicitly political in content and consequences. Over the next decade, the $A I Z$ became the most concrete vehicle in a leftist photography movement that treated each act involved in making, presenting, and looking at photographs as inherently political. The perspective that emerged from the resulting photographs deserves examination, not only because of the time and place in which this movement arose, or for its significance in the rise of the picture press, but also because of the beliefs about photography that shaped the practice and appearance of the work itself.

\section{Rise of the Picture Press}

When Willi Münzenberg needed a forum for the Internationale Arbeiterhilfe (Workers' International Relief, or $(\mathrm{AH})$, he established Sowjet-Russland im Bild (1921), whose title was changed after 12 issues to Sichel und Hammer. In 1924, it became the Arbeiter-Illustrierte Zeitung. ${ }^{1}$ The $A l Z$ remained the principal organ of the $\mathrm{IAH}$, which Münzenberg used as an umbrella organization to bring together a broad spectrum of leftists and liberals in support of humanitarian causes. His eclectic interests, engaging manner, and broad vision helped him build a broad but loosely structured coalition.

Many of the writers, artists, and intellectuals Münzenberg attracted to IAH were willing to lend support to other causes and provided much of the material used in the growing number of publications the Communist party was distributing. In addition to the $A I Z$, with a circulation approaching 500,000 , these included the humor magazine Der Eulenspiegel and the daily newspapers Berlin am Morgen and Welt am Abend, for a combined circulation of over 400,000 (Gruber 1966:288). Münzenberg rejected the narrow definition of a party press: these publications were all intended to stimulate a general feeling of solidarity among workers, not only in Germany, but around the world. The $A I Z$, as a picture magazine, was seen as having powerful potential in this regard. 


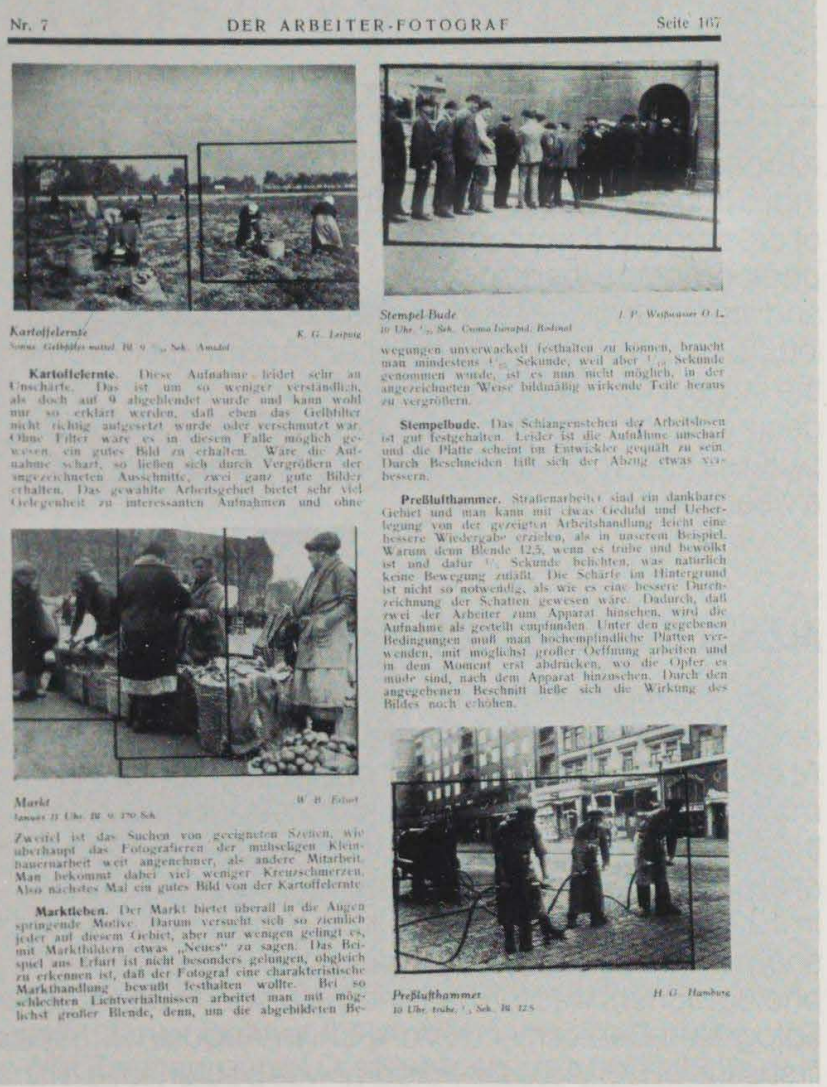

Figure 3 Photographic evidence of misleading pictures used by the MIP to create the impression of an economic upswing. Arbeiter-IIlustrierte Zeitung, Volume 11, Number 50 (1932), pp. 1164-1165.

The magazine was assembled by a small staff. Even during its most successful period, from 1927 to 1933 , there were only five staff members. Lilly Becher, the editor, had begun her journalistic career with the Ullstein publishing house, then worked from 1921 to 1926 on the editorial staffs of several Communist publications. She became editor in chief of the AIZ in 1927. Her chief assistant was Hermann Leupold, formerly a toolmaker, who was responsible for the layout of the magazine. ${ }^{2}$ In addition, there was a picture editor who also acted as archivist, an artist responsible for drawings, and a stenographer. According to Becher, different names were often used to give the impression that a large staff contributed to the making of each issue. She also acknowledged that the staff kept close contacts with the Communist party and the revolutionary part of the working class (Willmann 1975:7). ${ }^{3}$

The $A I Z$ 's broad range of content-from sports, puzzles, and columns for children to topics of international labor and politics - was liberally illustrated with photographs. While subscribing to the condescending notion of the viewer as easily seduced by photographs, Münzenberg also recognized the competition the $A I Z$ offered to other illustrated magazines:
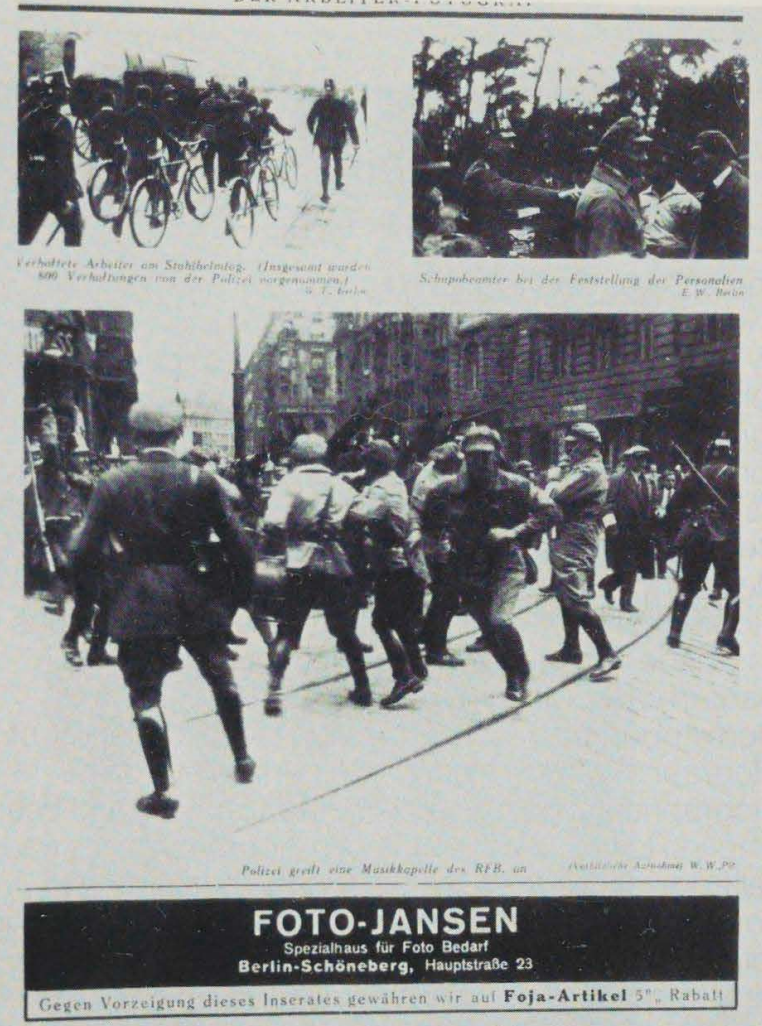

The picture has an effect particularly on children and young people, on those with simple thoughts and feelings, on not yet organized, indifferent masses of workers, farm laborers, tenant farmers and other classes.... Even considering just the distribution, it is easier to sell an illustrated magazine to an indifferent worker than a theoretical brochure. It must be possible to successfully counteract Verdummung through bourgeois illustrated magazines which are circulated in the millions in Germany with an illustrated workers' magazine. [Münzenberg 1925:57]

Thus he saw the $A I Z$ as part of a counter movement to the bourgeois media awakening people from the stupefying effect of the established press and the photography that dominated it. ${ }^{4}$

The media's increased use of photographs in both advertising and journalism was linked to the authority of photographs as documents. At a time when a concern for realism had inspired a new movement in German art and expression, photographs had great appeal. The insistent belief in photography's power to document "things as they are" gave the medium a natural place within "Neue Sachlichkeit," and was a major reason for its expanded role in the mass media. Münzenberg saw the $A I Z$ as an opportunity to apply this belief in the authenticity of the photographic record to conditions of proletarian life. 
The $A I Z$ was able to take advantage ot other conditions that were paving the way for photographs' widespread entry into the press: the low cost and accessibility of photographic equipment, relative ease of reproduction, and the growing number of people interested in making photographs for a living. And since the broad scope of the AlZ's coverage overlapped with other picture magazines, those photographs might have been considered appropriate for the AIZ's pages. However, some professional photographers objected to the ways their photographs were "made less credible or falsified through political slogans in captions" in the AIZ (Gidal 1973:26).

More important than the question of the availability of photographs was the identity and perspective of the photographers who made them. Münzenberg had been attempting to remove the distinction journalism has traditionally drawn between producer and consumer by encouraging readers to contribute to the magazine. This practice was more than an attempt to get material to print: Münzenberg was consciously confronting the premise of objectivity that dominated professional journalism. When the journalist is a member of the audience that is being addressed, self-interest can become one with the interest of that audience. This perception of photographers constitutes a further departure from the premise of objectivity by Münzenberg, for it acknowledges that photographs are not determined by technology or chemistry, but are shaped by the interests of the people who make them.

From the perspective of the $A I Z$, the camera was a means of expressing a partisan, ideologically charged point of view. Lilly Becher suggests that the workerphotographer movement was consciously guided by the small team of $A l Z$ editors who recognized their own revolutionary task and who instilled in their contributors a strong sense of class consciousness that led to the kind of social reportage that drew widespread attention and offered "something qualitatively new" (Willmann 1975:8). Thus, amateur photographers began to document the living and working conditions of their own environments. By photographing the day-to-day routines of their coworkers, friends, and families, they were also gathering evidence of the oppression of the working class under the capitalist system.

The workers who engaged in this photographic documentation were doing more than producing illustrations for a magazine; photography was a vehicle for their active participation in the class struggle. In pointing to differences between social criticism among bourgeois and worker photographers, it has been suggested that the work of Jacob Riis and Lewis Hine, for example, was aimed at showing isolated events and always remained a bourgeois interpretation of the working class. Workerphotographers, on the other hand, recognized social criticism as the basis for their involvement, and it served as a guide toward a new vision of their class (Beiler 1977:85). Their individual and coordinated efforts served a broad educative function by confronting the effects of those images that dominated the mass media. The act of creating such photographs was to affect the workerphotographers themselves, mobilizing them as active and insistent voices for their class and for the German left. To be a worker-photographer thus meant to admit the subjectivity of one's approach, to overcome the bourgeois influence upon the activities of viewing and taking pictures, and to use the camera quite consciously as a weapon.

\section{AlZ and Worker-Photographers}

The AIZ relied heavily on photographs by amateurs and remained the major outlet for the worker-photographers. At first, photographers were identified by name in the magazine, but later, to protect their safety and to signify the unity of their photographic efforts, their work was often labeled only "Arbeiterfotograf" (Rinka 1967:30). In 1926 the AlZ organized a photography contest, and soon afterward a national organization of workerphotographers was formed, the Vereinigung der ArbeiterFotografen Deutschland (VdAFD). In August 1926 the first issue of Der Arbeiter-Fotograf was published, a magazine specifically for worker-photographers. The AIZ, VdAFD, and Der Arbeiter-Fotograf served as the major means for building workers' interest in photography into a movement, encouraging a variety of public outlets and stimulating organized activities on the local, national, and even international levels.

The first national conference of the VdAFD in Erfurt (April 17, 1927) was attended by representatives of 25 groups in Germany and five representatives from foreign countries (U.S.S.R., Czechoslovakia, Great Britain, and Belgium) (Beiler 1967:48). Two years later, at the second national conference in Dresden, 24 organizations with 1,480 members were represented (Danner 1967:21). The German worker-photographers cooperated closely with their Soviet counterparts. In 1930, this resulted in Unionfoto G.m.b.H. (later called Union-Bild), a picture service combining German and Soviet interests that included Russ-Foto, the largest picture agency in the U.S.S.R., the secretariat of the Allrussian Workers' Photography Clubs, and several Soviet publishing houses. Workers' photography groups were also formed in several European countries and the United States (Danner 1967:22), and photography courses were offered at the Marxist workers' schools in Berlin and Leipzig.

As new groups were formed ( 16 between October and December 1927), exhibitions were organized and pictures were contributed to newspapers and magazines published by labor unions, the Communist party, and the Social Democratic party. Within these clubs or collectives, the photographers discussed their work, carried out joint projects, and maintained public bulletin boards of their recent photographic activities. Many clubs extensively 


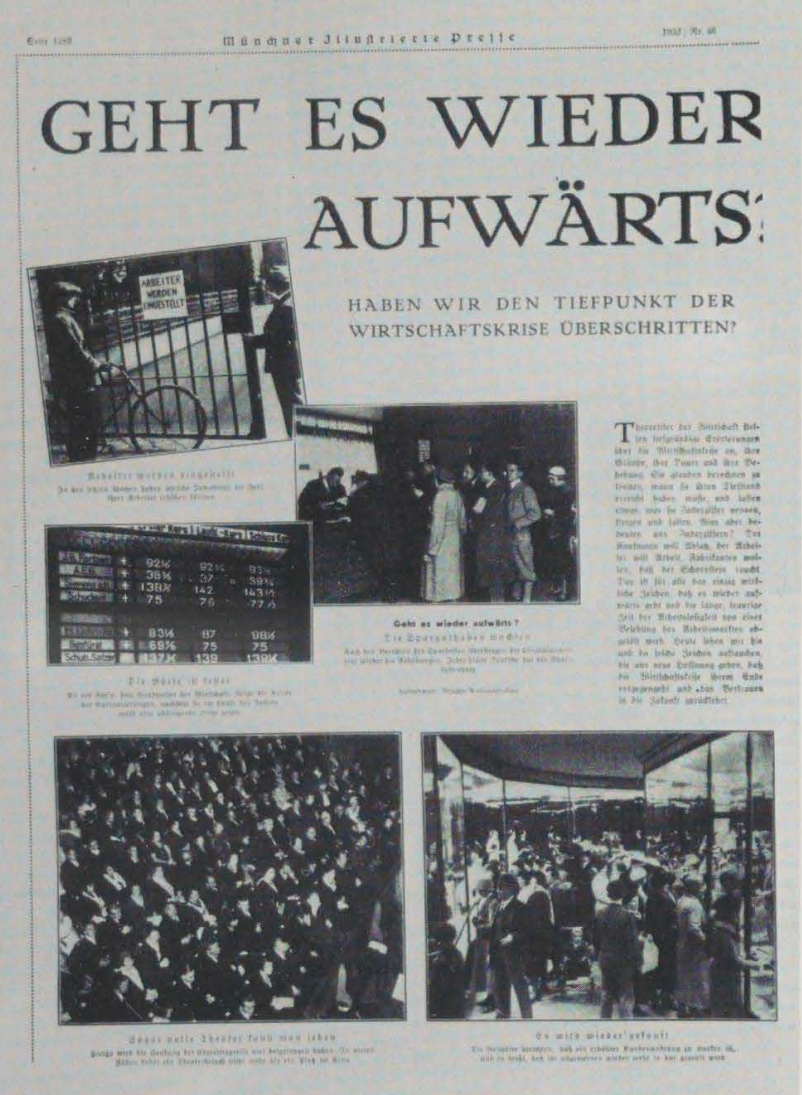

Figure 4 Cover features the prize-winning photography (by Willi Zimmermann of Dresden) used as a postcard to recruit worker-photographers. Der Arbeiter-Fotograf, Volume 2, Number 11 (1928), p. 3. (From Joachim Büthe et al., Der Arbeiter-Fotograf-Dokumente und Beitrage zur Arbeiterfotografie, 1926-1932. Köln: Prometh Verlag GmbH, 1977 , p. 53.

documented a single "typical" worker's family. They also carefully coordinated their coverage of political demonstrations to insure that the film (if not the photographer) would stay out of police hands. Many groups were highly productive: one of the largest, in Leipzig, reported sending about 150 photo series to various publications over a 2-year period (Der Arbeiter-Fotograf 1928:11, 15).

The clubs also had access to Der Arbeiter-Fotograf, where they found information and analysis addressing many facets of their work. In articles about the art of photography they could read about and see examples of how others approached their work. A sensitivity to patterns of light and shade in everyday objects, for example, as seen in the photography of those working at the center of the Neue Sachlichkeit movement, was discussed. Examples of Soviet photography were frequently published, introducing German photographers to the perspectives of other socialists. Other articles focused on philosophical discussions of the relationship between art and labor, and the problem of integrating artistic expression with political struggle, stimulating workers to develop new concepts of the subjects they photographed.

Articles on technical subjects in Der Arbeiter-Fotograf introduced specific techniques, stressing inexpensive alternatives to photographic problems. Readers could learn how to make certain items, such as a flash unit, that might not otherwise be available to them. Each issue

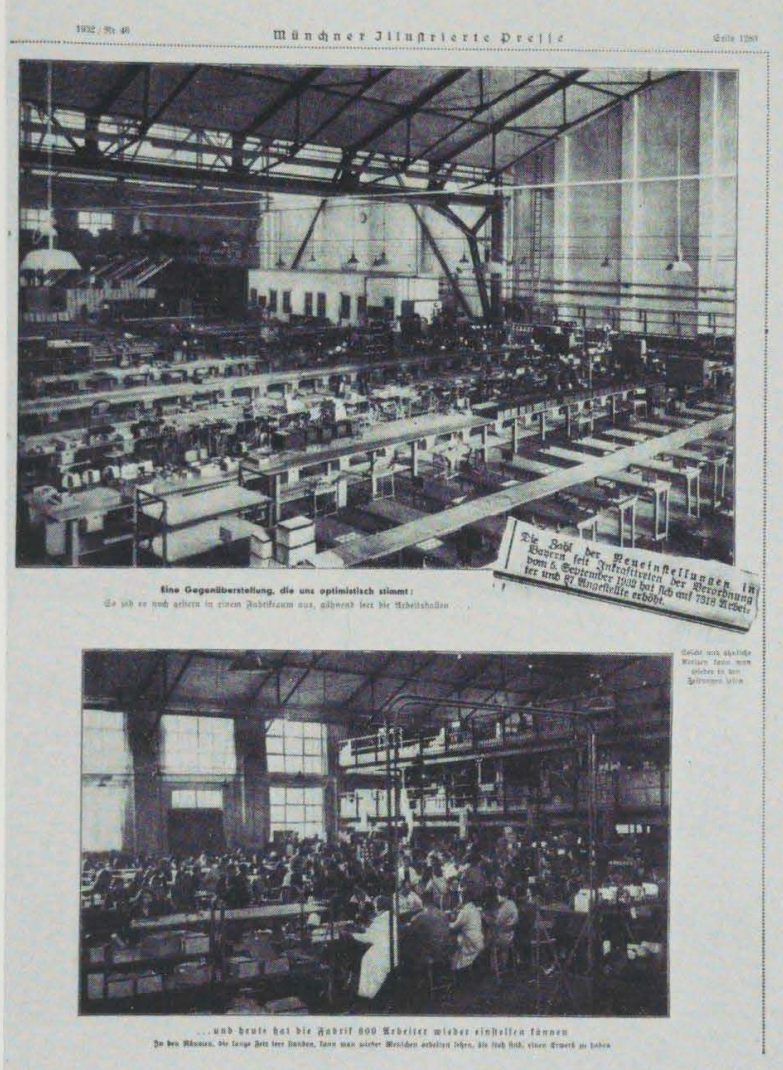

Figure 5 "Bilderkritik," in Der Arbeiter-Fotograf, Volume 4 Number 7 (1930), p. 166. (From Joachim Büthe et al., Der Arbeiter-Fotograf-Dokumente und Beitrage zur Arbeiterfotografie, 1926-1932. Köln: Prometh Verlag GmbH, 1977, p. 114.)

also included a feature titled "Bilderkritik, " offering specific criticism of work that individual photographers had submitted to the publication. By 1929 Der Arbeiter-Fotograf reported a circulation of 7000 (Danner 1967:21) and was a major outlet for photographs by workers. Certainly its availability was contributing significantly to the style and approach its readers were developing.

The impact of these sources of inspiration and support can be seen primarily in the pages of the $A I Z$, which remains the most accessible source for examining the work of these photographers. The general subject matter of the AIZ's photographs continued to overlap considerably with the topics covered by other picture magazines. The daily life of common people, the institutions that shaped those lives, the prevalence of sport, and the turmoil of political struggle and change dominate the photography published in the German press during this period, and the $A I Z$ was no exception. The workerphotographers could be expected to approach these prominent themes from a different perspective, however, given the social and political environments in which they were working.

German workers were not the only photographers supplying material to the AIZ. The worker-photographers perspective, while well represented in the magazine, did not constitute the AIZ's only window on the world. Regular features included pages of photographs from a variety 


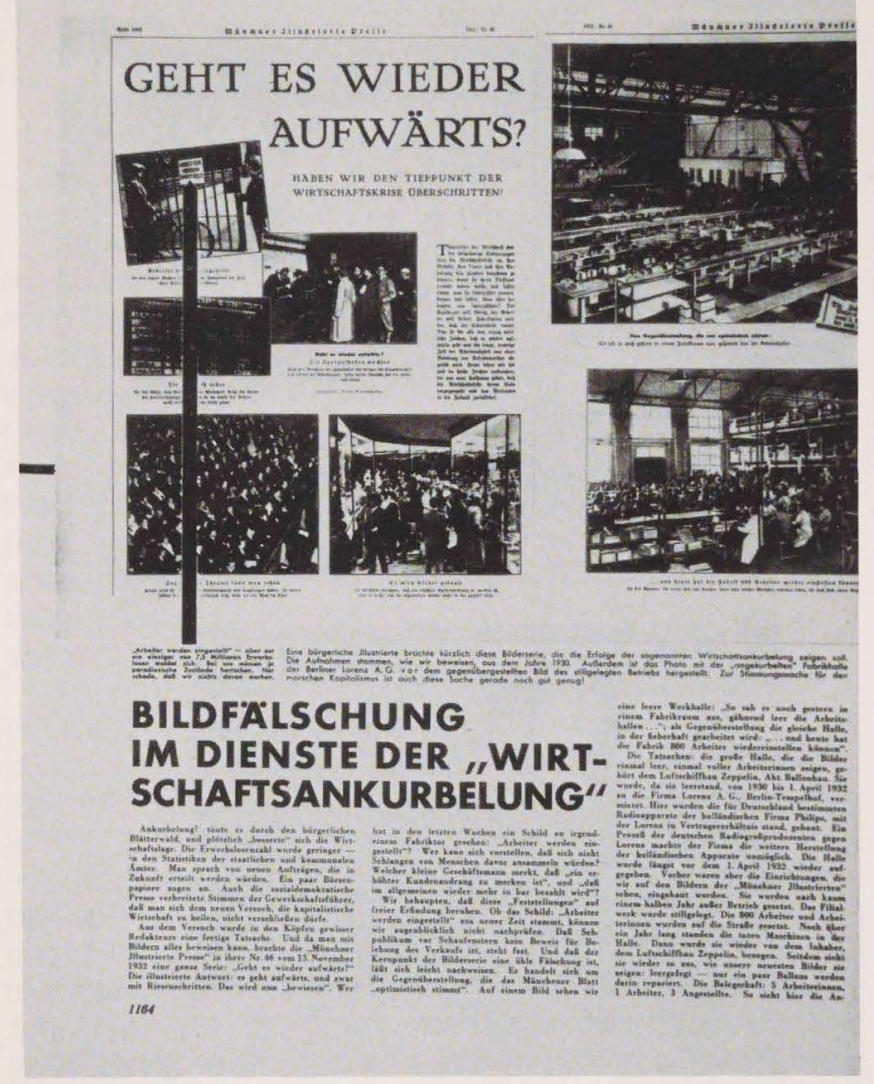

Figure 6 Politics in the streets: a report in the MIP. Münchner Illustrierte Presse, Volume 10, Number 24 (1931), p. 787

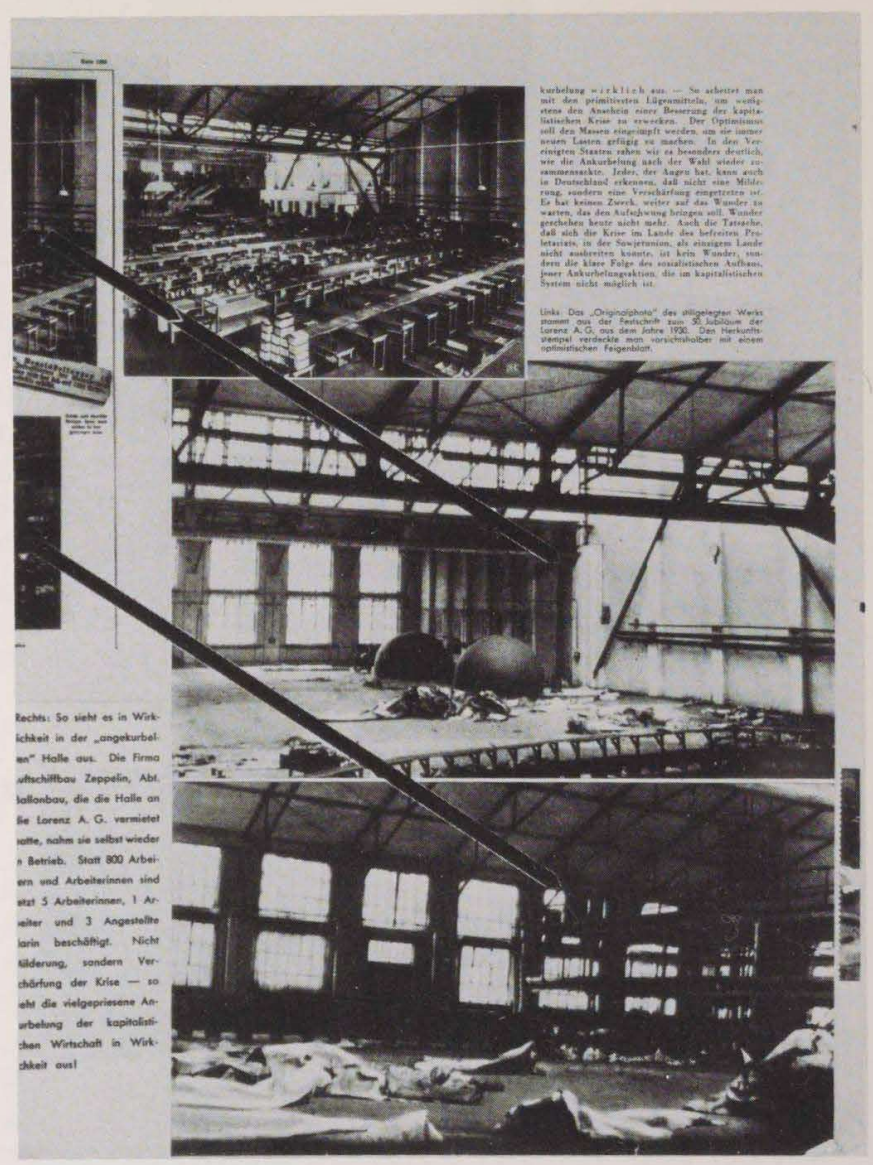

Figure 7 Der Arbeiter-Fotograf, Volume 2, Number 10 (1928), p. 7. (From Joachim Büthe et al., Der ArbeiterFotograf-Dokumente und Beitrage zur Arbeiterfotografie, 1926-1932. Köln: Prometh Verlag GmbH, 1977, p. 204.) of picture services showing recent events from other parts of the globe ("Aus aller Welt," one such feature, carried photographs captioned in Esperanto to underscore the magazine's international appeal). Nor did the $A I Z$ 's frequent use of photomontage rely heavily on the output of the worker-photographers' movement. John Heartfield's work exerted the strongest influence on the magazine in this regard: by combining multiple images into a single pictorial representation, Heartfield linked specific events to their political and social consequences in montages that remain unequaled in their graphic emo tional power. Although other editors, in particular Lorant admired and published Heartfield's work, it was seen most frequently in the $A I Z$. Often a Heartfield montage appeared on the cover and in the center double spread of the magazine.

Montage techniques were also incorporated into the $A I Z$ 's display of series of photographs, and these series usually included photographs by workers. Backgrounds were often dropped out and multiple images morticed into and laid over each other on pages incorporating as many as ten or twelve single photographs. Policemen's guns were pointed into adjacent photographs of demonstrating workers; construction workers strode into photographs of the new factories they were building; photographs of women holding up their hungry children were laid over scenes of mass demonstrations. Not all the AIZ's pages were so heavily worked, and occasionally workers' photographs were presented more simply, as series of individual photographs with accompanying text. Photographic series by workers became more common as the magazine matured, and by 1932 each issue carried one or more of these picture stories. There were still no staff photographers, and workers provided a majority of the magazine's photographs

It is clear that conditions existed for a widespread movement. A political philosophy explicitly defined the role photography and photographers should play in building proletarian solidarity. An organizational structure had been established, magazines existed to publish photographs by workers and to provide guidance to workerphotographers, and local groups provided personal contact with other worker-photographers and a base for coordinated action. Five years after its creation, Heinrich Mann could write in a letter to the $A I Z$ that the $A I Z$ succeeded in showing a proletarian world that did not exist for other illustrated magazines, and Siegfried Jacobsohn, founder of the Weltbühne, commented, "The ArbeiterIllustrierte is the best picture magazine that has ever come to my attention in Germany. Why? All possible reasons are insignificant except for the one that counts in the intellectual arena: it has character, quite simply character (Willmann 1975:34,36).

The photographs published in the AIZ and Der ArbeiterFotograf now provide the key to this "character" and form the primary basis for assessing the impact of orga- 


\section{Den Ximbitens Ertogrnat \\ Offizielles Organ der Vereinigung der Arbeiter-Fotografen Deutschlands}

\section{UN SERE WERBEPOSTKARTE}

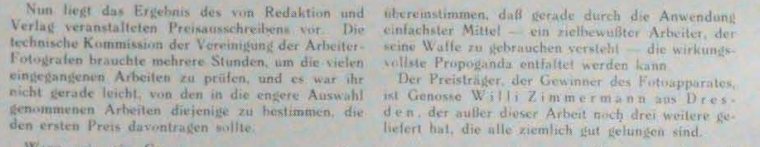
Wenn wir ein Ge.

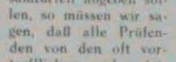
den won den oft vir.
treillichen und wrig. Arbeiten zuserunde is. Aleb, iberravectil waren die Bessatisumg dafin Chalten dab unserc Warten Fotomontus ansebrachit war. den wurde durch Zasa Bilder unibersichticict thing also in ihrer Wirh kamkeit verloren. N Nich
das Plakat witkt. au den móglichst viel wenn auch nar Richt. teht, sondern da. tiken klaren Wort Aufgaben und Ziel him
ausschreit! Auschrent) Wenn der leser den Entwurt der Werteposikarte betrachtel
wir den sich die Prei. ichier entschieden hil-
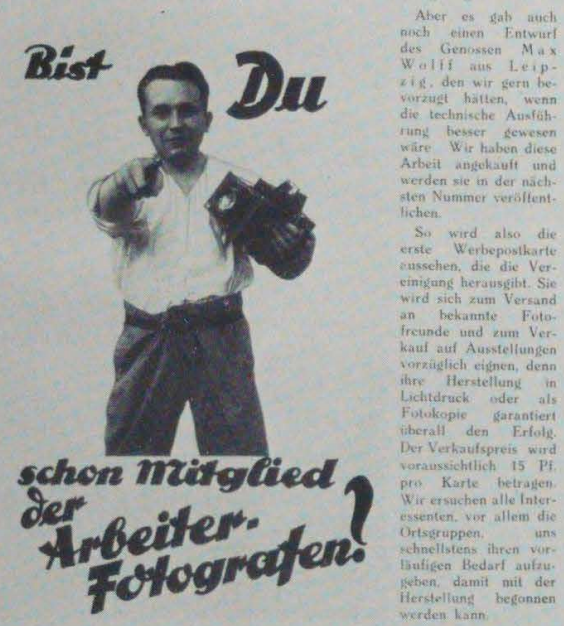

Figure 8 A picture story of a young proletarian, his life at home and at work. Der Arbeiter-Fotograf, Volume 1, Number 12 (1927), pp. 7-8. (From Joachim Büthe, Der Arbeiter-Fotograf-Dokumente und Beitrage zur Arbeiterfotografie, 1926-1932. Köln: Prometh Verlag GmbH, 1977, pp. 182-183.)

nizing workers as photographers. Although the number of workers who made and published these photographs and the size of their audience cannot be estimated with any accuracy, from the content and form of their published photographs one can see to what extent the network of support resulted in a coherent and consistent political style of photography, a pattern of expression that distinguished worker-photographers from other press photographers of their time.

\section{Worker-Photographer Style}

Workers' photographs published in the $A I Z$ and Der Arbeiter-Fotograf show that a style emerged within this group. Repetitions evident in the subject matter of the photographs and in the camera techniques used, particularly in framing and composition, suggest that workerphotographers developed a coordinated pattern of expression suited to the political aims of their movement; their work incorporated aspects of several different approaches to photography.

First, they worked as many amateurs do; their photography is similar to folk or family photography. The frequency of group photographs, usually arranged in a symmetrical composition, has a corollary in the many photographs of groups seen in family collections since

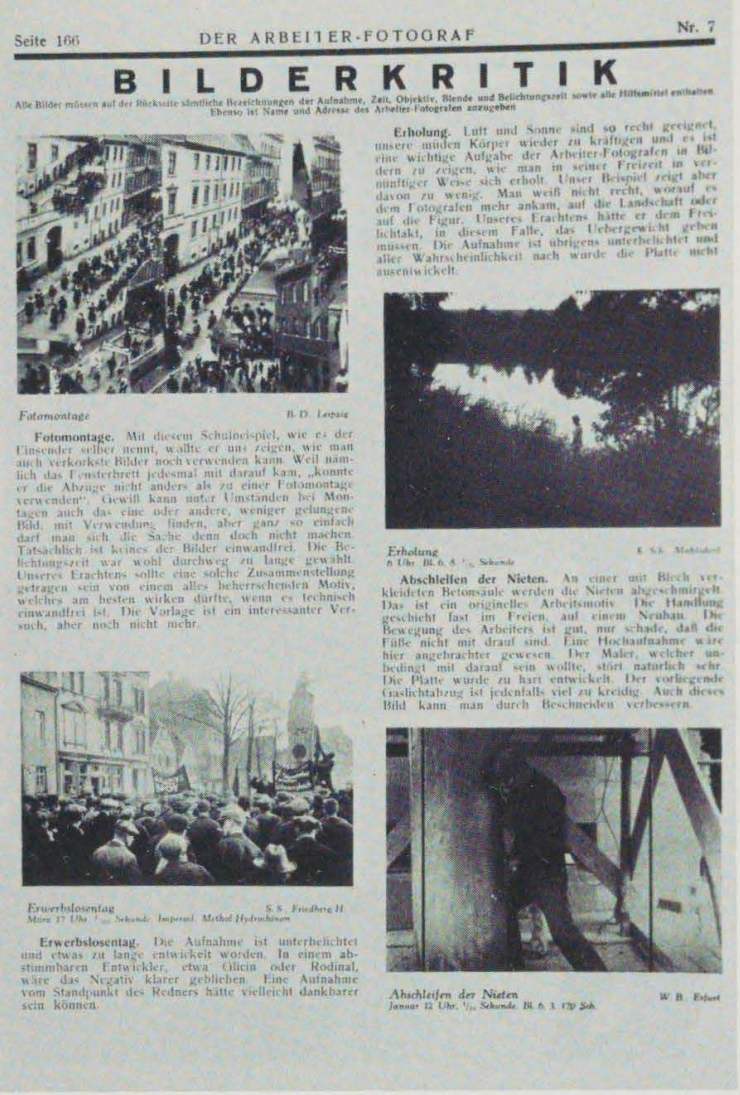

the turn of the century (Chalfen 1975, Ohrn 1977). The effect of overt posing is seen, as people stare stiffly at the camera or smile with raised fists in apparent response to the photographer's request. The photographs tend to define the scene broadly; the loose framing and placement of the primary subject or group at its center conforms to the amateur's definition of subject and background The common-sense assumption that showing "the whole scene" means framing the principal subject with even amounts of space top and bottom, left and right, is evident.

The way these formal stylistic features present the subjects of the worker-photographers differs from those photographs anchored in the "home mode" tradition, however. The wide view, symmetrically composed, is well suited to showing large crowds in the streets and rows of workers taking a break to pose for a photograph. It emphasizes repetition of the human form and the settings in which the subjects are found, thus suggesting a political and social interpretation by the photographer. In contrast to the "personification" of events in the bourgeois press (Hall 1973:183), the theme is not one of individuals, but of a mass - even "the masses" - of people engaged in a coordinated activity. The context of that activity, whether in the streets or in the work place, defines their role, while the size of the group suggests their power to define the setting as their own, one in which they, as a group, assert control. 


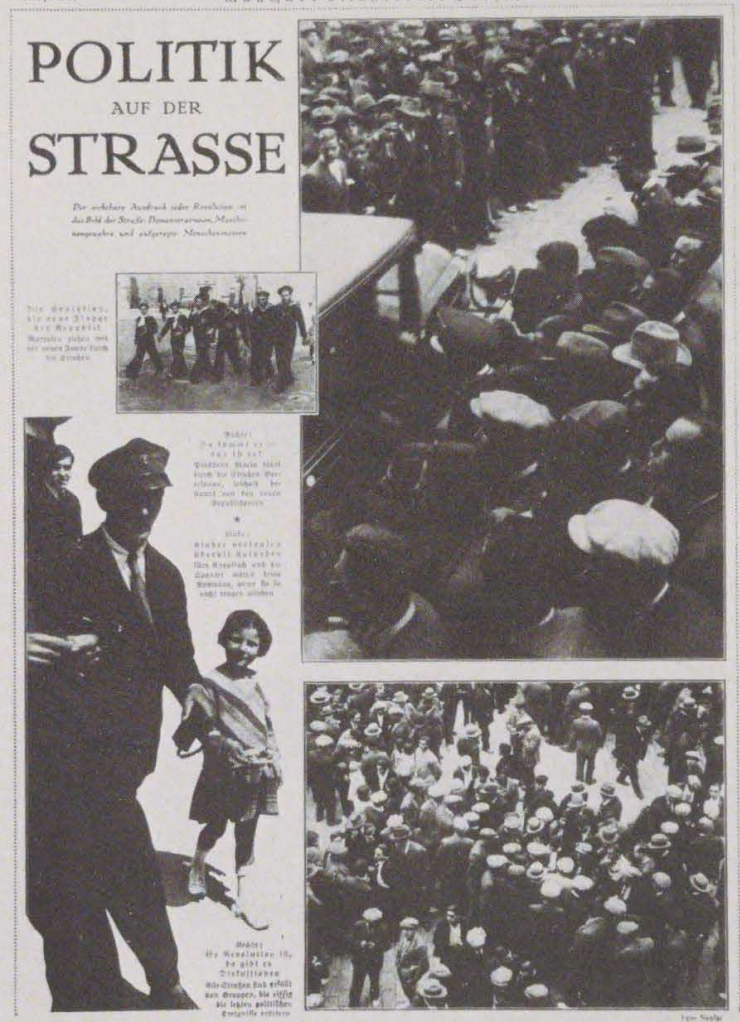

Figure 9 Photographing the work-place: the demolition of a building. Arbeiter-IIlustrierte Zeitung, Volume 7, Number 40 (1928), pp. 8-9.

The evident posing of photographs in which people are gazing at the camera expresses a theme central to the amateur family photograph collection - that of agreement between the subject and the photographer. Agreeing to stand and be photographed is an admission of the power of the photographer over the subject. When the quality of the photographer's authority is coercive, the result may be extreme, as, for example, identification photographs in police files. However, when the photographer's authority stems from his or her role as an accepted member of a group, the sense in which the individual or group agrees to be photographed, if not strictly egalitarian, is certainly cooperative. The resulting photograph, as in the case of many of the worker-photographer group shots, expresses the photographer/subject relationship as one of shared, positive understandings of the purpose for which the photograph is being made.

In other respects, the style of the worker-photographers more closely paralleled another approach, seen most clearly in photographs made as part of extended documentary projects. Working environments and working conditions were approached as integral parts of a person's life and not as behind-the-scenes activities often ignored by the media. A worker photographing his wife, for example, did not employ the conventions used by the family photographer, but recorded her daily routine. The theme
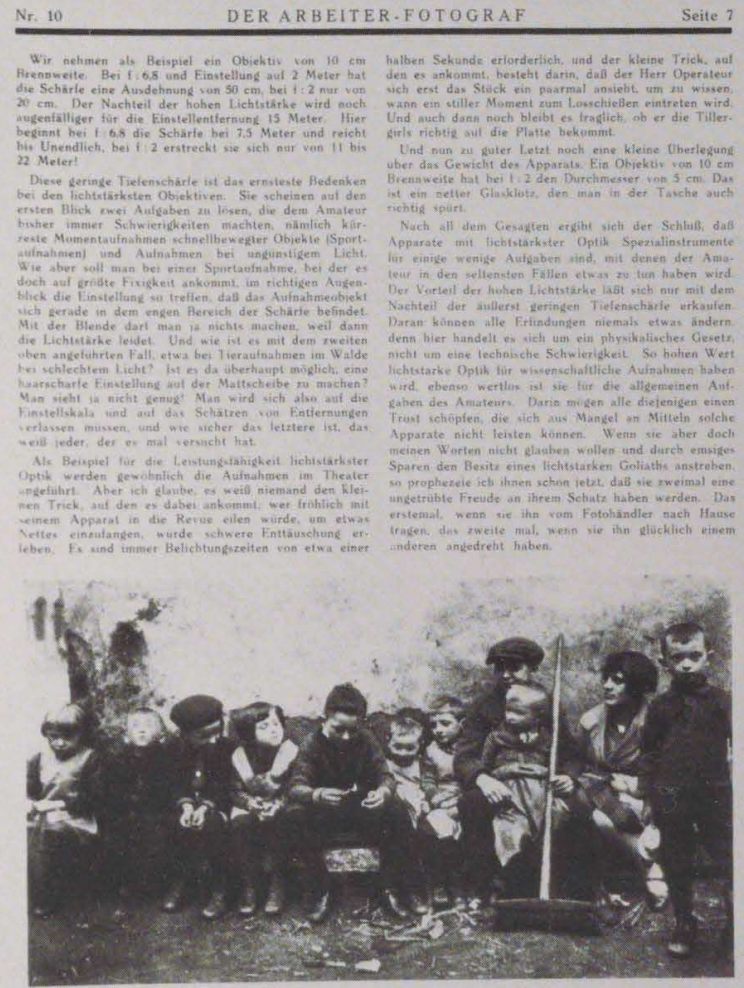

of "a day in the life of a worker" showed up frequently in the pages of the $A I Z$, indicating a more analytical vision than that of the characteristic amateur. Photographing the step-by-step process of a particular job was another common topic. The camera work in most cases was straightforward - camera angle rarely deviated from normal eye level, and the distance between photographer and subject tended to be held constant.

This recognition of the activities of the poor and working class was admittedly propagandistic, an intention common in documentary movements. As Dorothea Lange later said about her work for the Farm Security Administration (FSA) in the United States during the 1930s,

"Everything is propaganda for what you believe in, actually, isn't it?...The harder and more deeply you believe in anything, the more in a sense you're a propagandist" (Lange 1968:181). The German worker-photographer would have agreed. A correspondence between the FSA photography in particular and the worker-photographer in Germany is freely acknowledged (Hiepe 1978:18-19). The importance of selecting and photographing previously undocumented groups and individuals was an explicit purpose of the FSA project, and several of the photographers, most notably Russell Lee, chose the analytical step-by-step approach to record their activities. Lewis Hine's documentation for the Pittsburgh Survey 
DER ARBEITER.FOTOGRAF

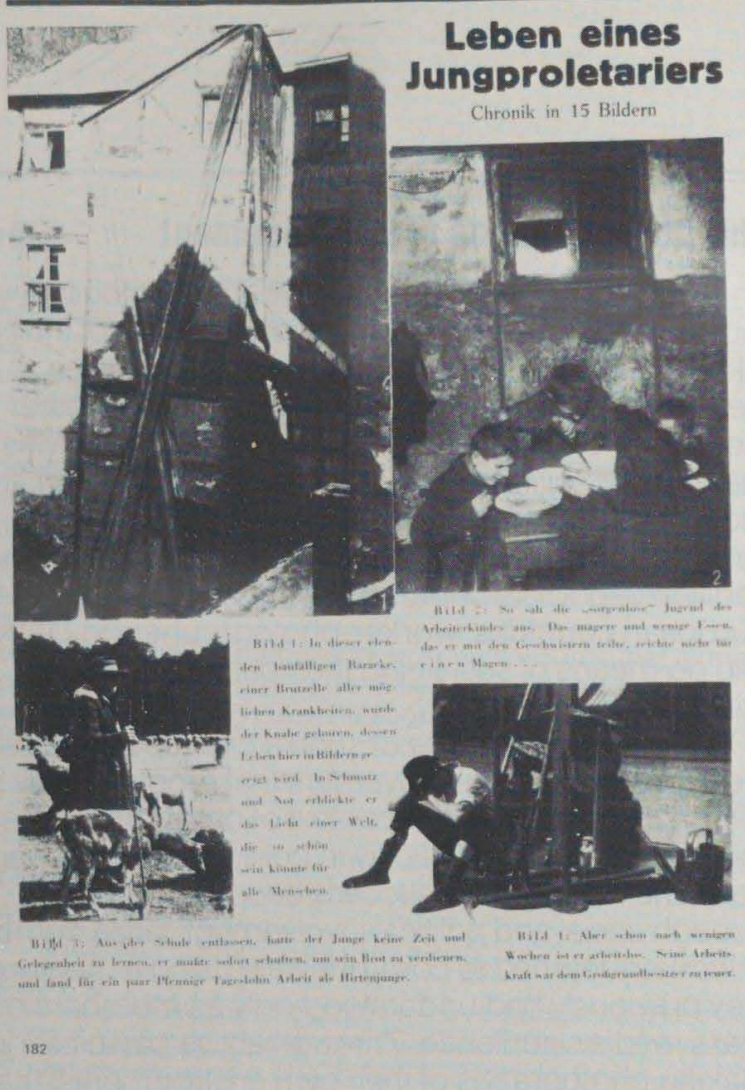

Figure 10 "Bilderkritik," in Der Arbeiter-Fotograf, Volume 4, Number 7 (1930), p. 167. (From Joachim Büthe et al., Der Arbeiter-Fotograf-Dokumente und Beitrage zur Arbeiterfotografie, 1926-1932. Köln: Prometh Verlag GmbH, 1977 , p. 115.)

and the National Child Labor Committee in the early twentieth century also parallels the approach used by the German photographers. Each of these projects departed from the common tendency to select better-known leaders of society and usually avoided artful camera technique. The political implications of this approach are clear: they show in a direct manner the living and working conditions of the lower ranks of society and at the same time draw attention to that society's dependence on the activities of the working class. However, the overt political style of the German worker-photographers was further heightened by their identification with their subjects. Their firsthand experience with the people and activities they photographed gave them more intimate access to these subjects. The authority of their photographs thus conveyed the authenticity of a participant's perspective.

In other respects the worker-photographers were working as photojournalists, and their work shared components of a style that was becoming evident in the German picture magazines of the period. Although their photography was not always tied to an event considered newsworthy in the conventional sense, they were avid in their coverage of street demonstrations. They appear to have considered themselves watchdogs in the frequent confrontations between workers and the police: their photographs focus on police treatment of workers. When

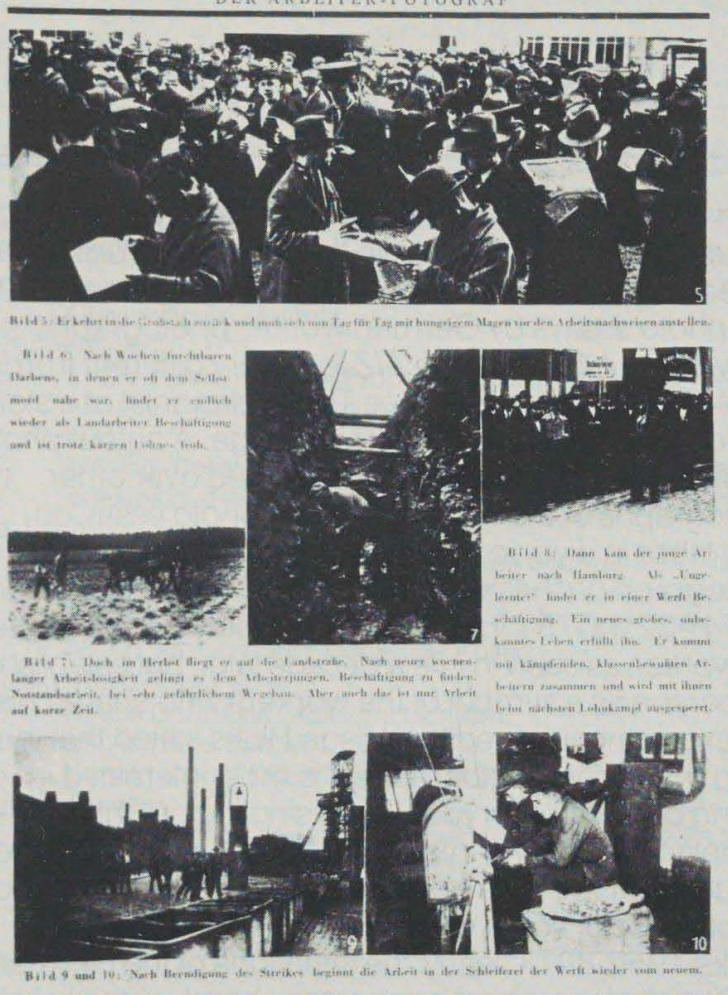

183

Figure 11 The arrest of workers; the large photograph (by Wide World) is used as a good example of an action picture. Der Arbeiter-Fotograf, Volume 1, Number 11 (1927), p. 5. (From Joachim Büthe et al., Der Arbeiter-Fotograf-Dokumente und Beitrage zur Arbeiterfotografie, 1926-1932. Köln: Prometh Verlag GmbH, 1977, p. 243.)

documenting the ongoing activities of workers, they often used the journalistic approach of selecting an angle, usually a particular worker or family, and tried to photograph as if through the eyes of their subject. By selecting a single individual as a protagonist, they could "tell a story" that represented the experiences of a broad segment of society, using an approach closely parallel to the photojournalists'. Particularly when making a series of photographs, they began to employ a variety of camera angles and distances from their subjects, looking for details, action, close-ups of faces, and overviews of the scene.

The "Bilderkritik" feature in Der Arbeiter-Fotograf encouraged this approach. Photographs submitted by workers were cropped to show a tighter focus on one figure, and new frames were drawn on overview photographs to demonstrate other parts of the scene deserving closer attention. By explicating these rules of composition, "Bilderkritik" was helping photographers shape their work to the photo essay form. Ways of improving their work in this regard were also a common topic of discussion within the worker-photographer groups.

A parallel kind of instruction was used in at least one group of American photographers. The head of Life magazine's Detroit bureau helped a group of factory workers develop an ability to locate stories and taught 
them the "formula for shooting photo essays, bringing about a significant increase in the coverage from Detroit appearing in Life in the early 1950s" (Dykhouse 1979). The photo essays by German worker-photographers that were published in the $A I Z$ look very different from Life's photo essays, however. The protagonist of a story was often worked into a photomontage. A cutout photograph of this person might be displayed over other photographs of the work place. In a photo essay on child labor in a yo-yo factory, for example, the largest photograph on the page is of a single unidentified child (AIZ 1932:1,075). This technique did not individualize the worker, as seen in Life a decade later, but established the person as a symbol of the workers who shared his or her experience. Life editor Wilson Hicks stated that the good magazine photographer "is most interested in finding drama in everyday life, in singling out the commonplace, in delving into human problems; unlike the documentarian, he is not interested in doing so only for the purpose of social criticism or to plead a cause (Hicks 1952:88). Clearly, the intentions of the German worker-photographers contrasted sharply with Hicks's ideal. Despite the photojournalistic conventions they used to document workers' lives, the worker-photographers' goal was to level a radical critique against capitalist repression, a goal achieved in part through the way their work was displayed in the $A I Z$.

The expressions of the worker-photographers can thus be seen as fusing aspects of three styles - that of the amateur family photographer, the documentarian, and the magazine photojournalist. It was the workerphotographers' identification with their subjects that linked components of these separate styles and at the same time distinguished their work from that of others during that period. Unlike the photographs appearing in other German picture magazines, their work grew out of an active participation in the events they photographed, and this perspective created reciprocal identification with their intended audience.

The perspective was underscored in the pages of Der Arbeiter-Fotograf: "We take pictures where proletarian life is the toughest, where the bourgeoisie is rotten to the core.... The picture is a weapon, technique is a weapon, art is a weapon....We are the eyes of the proletariat. We teach our brothers to use their eyes" (Hoernle 1930:154). The class-conscious readers could thus see events as if through their own eyes, with the added political inflection intended to enhance their awareness of the oppression they experienced in common with the people in the photographs and the men and women who created them. Through its photography, the $A I Z$ became their publication, truly a "medium of the masses," providing visual proof that the bourgeois press was misrepresenting the events they were experiencing firsthand.

\section{The Consequences of the Movement}

The destruction of the German worker-photography movement was one of the immediate effects of the Nazi takeover in 1933. The AlZ was moved to Prague, Der Arbeiter-Fotograf ceased publication altogether, and the worker-photography clubs disbanded. As an instrument of opposition to Nazi power and oppression, the movement must be judged a failure. Despite apparent threads of continuity, as seen for example in the lively tradition of political photomontage carried on in other European countries, worker-photographers in Germany had no means of sustaining their particular political critique.

Yet the mere existence of such a critique suggests the significance of the movement that produced this body of work. Examined in the context of beliefs about the role photography could play in politicizing the working class, the movement's success becomes apparent: through social and political involvement, large numbers of workers learned to communicate using a medium they previously had understood only as members of the mass media's audience. Through active participation in making photographs of their own environments, they overcame any barriers presented by lack of formal education or the cost of photographic equipment and production. By consciously assuming a political perspective, they learned that photography could be used to express a point of view and, by extension, that all photographs do so.

A heightened consciousness of the political content inherent in symbolic forms pervaded German art and expression during the years of the Weimar Republic. At the time the worker-photography movement was at its peak, Kurt Tucholsky wrote, "As there is nothing that is not political in this world, there cannot be any nonpolitical photography" (Tucholsky 1930). Among those workers who had learned to use photography as a political weapon, there developed a pattern of work and a visual style that reveal a radical perspective and critique of prewar Germany available nowhere else. 


\section{Notes}

1 The $A / Z$ was moved to Prague in 1933, and in 1936 the title was changed again, to Volks-lllustrierte. The magazine ceased publication in 1938 .

2 Becher went into exile, first in France (1933-1935), then in the Soviet Union (1935-1945), where she continued her journalistic career. She returned to the German Democratic Republic and became editor of the Neue Berliner Illustrierte until 1951. Hermann Leupold became copublisher of the AIZ with F. C. Weiskopf when it moved to Prague. He emigrated to England in 1938. After his return to East Berlin he became director of the Berliner Verlag

3 Translation from the German of this and the following citations by the authors.

4 The most recentaccount of Münzenberg's contribution to the German illustrated press is in an article by Ute Eskildsen, "The A-I-Z and the Arbeiter Fotograf: Working Class Photographers in Weimar," published in Image 23:2 (1981):1-8.

\section{References}

- Arbeiter-Illustrierte Zeitung

1932 Yo-yo Macht Froh? 2(45): 1075.

- Beiler, Berthold

1967 Aus dem Woher ist das Wohin zu ergründen. In Berichte, Erinnerungen, Gedanken: Zur Geschichte der Deutschen Arbeiterfotografie, 1926-1933. Berthold Beiler, ed. Pp. 12-17. Berlin: Deutscher Kulturbund.

1977 Weltanschauung der Fotografie. Leipizig: VEB Kinoverlag.

- Chalfen, Richard

1975 Introduction to the Study of Non-Professional Photography as Visual Communication. In Saying Cheese: Studies in Folklore and Visual Communication, Folklore Forum. Pp. 19-26. Bibliographic and Special Series No. 13.

- Danner, Günter

1967 Eine Organisation von Kämpfern mit der Kamera. In Berichte, Erinnerungen, Gedanken: Zur Geschichte der Deutschen Arbeiterfotografie, 1926-1933. Berthold Beiler, ed. Pp. 18-23. Berlin: Deutscher Kulturbund.

- Der Arbeiter-Fotograf

1928 Vol. 2, p. 15.

- Dykhouse, Carolyn

1979 The Detroit Workshop and the Life Essay Technique. A paper presented to the Photojournalism Division, Association for Education in Journalism Convention.

- Gidal, Tim

1973 Moderi Photojournalism: Origin and Evolution, 1910-1933. New York: Collier Books.

- Gruber, Helmut

1966 Willi Münzenburg's German Communist Propaganda Empire 1921-33. Journal of Modern History 38(3): 278-297.

- Hall, Stuart

1973 The Determinations of News Photography. In The Manufacture of News; Deviance and Social Problems and the Mass Media. Stanley Cohen and Jock Young, eds. Pp. 176-190. Beverly Hills: Sage.

- Hicks, Wilson

1952 Words and Pictures. New York: Harper and Brothers.

- Hiepe, Richard

1978 Die Arbeiterklasse in der Fotografie. In Arbeiter-Fotografie. Pp. 6-24. Berlin: Elefanten Press Verlag GmbH.

- Hoernle, Edwin

1930 Das Auge des Arbeiters. Der Arbeiter-Fotograf IV:151-154.
- Lange, Dorothea

1968 The Making of a Documentary Photographer. Interview by Suzanne Riess. Berkeley: Regional Oral History Office, University of California

- Münzenberg, Willi

1925 Erobert den Film. In Propaganda als Waffe. Pp. 46-66. Frankfurt: März bei Zweitausendundeins.

- Ohrn, Karin B

1977 Making Belief: Contexts for Family Photography. Paper

- Rinka, Erich presented at the American Studies Association Convention.

1967 Die Arbeiter-fotografen-was sie waren und was sie wollten Berichte, Erinnerungen, Gedanken: Zur Geschichte der Deutschen Arbeiterfotografie, 1926-1933. Berthold Beiler ed. Pp. 26-34. Berlin: Deutscher Kulterbund.

- Tucholsky, Kurt (Peter Panter)

1930 Neues Licht. Das Deutsche Lichtbild.

- Von Eckardt, Wolf, and Sander L. Gilman

1975 Bertold Brecht's Berlin. New York: Anchor Books.

- Willmann, Heinz

1975 Geschichte der Arbeiter-Illustrierten Zeitung 1921-1938. Berlin: Dietz Verlag. 